\title{
John Gordon Edmeads (1936 - 2006)
}

\section{The Great Edmeads}

Reflections of a friend and former trainee

In the medical world, Dr. John Edmeads will almost certainly be most remembered for the unique and virtually unrivaled quality of the lectures and medical rounds he delivered, and for his similarly virtually unrivaled skill in treating patients with headache.

His clinical acumen in Neurology and Headache in particular earned him a reputation that reached so far and wide, that as residents, he was on more than one occasion called away from us to Buckingham Palace to treat a Royal family member with particularly disabling migraine.

Attending a lecture by Dr. Edmeads, was like spending an hour in the theatre. He had this extra-ordinary ability to educate you regarding the relevant medical information while interspersing, humor, allegory, medical history and fun always tempered with a strong dose of humility. In a lecture he gave on dementia once, he pointed out the importance of establishing whether the patient understood the reason for the consultation. "If after five minutes with the patient, you do not know what he is doing there," Dr. Edmeads stated, “I guarantee that one of you is demented."

John made learning fun, and in so doing always kept our interest. No one ever snoozed during a lecture by Dr. John Edmeads.

These same skills and techniques used at the lectern, were magnified in the teaching John did at the bedside. To go on bedside rounds with Dr. Edmeads was to be exposed to his infectious joy and enthusiasm for being a doctor. Not only were you going to learn a wonderful array of clinical pearls, but you were going to have fun doing so.
John had a unique voice and way of speaking that oozed inclusiveness, hospitality, humility respect and friendship. When you were in his presence there was sort of a feeling of home town goodness. You were never made to feel that you were in the presence of "The Great Edmeads", internationally acclaimed lecturer, professor, department chief, prolific author, editor of prestigious journals, and Neurologist to the Royal family. Rather, you felt that you were in the presence of a kind neighbour, or a loving uncle who was serving you up neurology with a slice of Aunt Bea's apple pie, and shepherding you through the trials and tribulations of being a medical student or trainee.

Although he will likely be most remembered for his teaching from the lectern and at the bedside, his greatest strength, I feel was his desire and ability to mentor and nurture trainees on a one to one basis. John was a true nurturer. I have heard a number of stories from my colleagues and will share a couple of my own.

As a resident, one time I expressed my concern about the amount of material to be incorporated and synthesized in order to master Neurology. Addressing me by name, as he always did with everyone, he told me "Neurology is not difficult. With a bit more knowledge and experience you'll be able to do it using only your thalamus." This is one of the many "Edmeadsisms" I have tucked away in my memory, and that I cherish. He also added a common characteristically modest phrase of his. "If I can do it, anybody can do it."

Another one of my own stories is from early in the first year of Neurology training. We were required to take a basic science exam, set up for American training programs, which were very different from our own. It was largely regarded as a ridiculous exercise by many of my colleagues who said that it was not worth preparing for. I heeded that advice. Nevertheless, when the Chairman of Neurology found out about my abysmal, 
performance on this test, I was instructed to go discuss the issue with Dr. Edmeads. Sensing my concern over the matter, Dr. Edmeads told me not to worry about it. "Have you ever seen a horse-race." he queried, addressing me by name, as usual. I admitted, that I had not. "Well, at the beginning of the race" he explained "you often see a horse at the back of the pack, but by the end, that horse is a winner." He continued his reassurance "Keep reading and keep working hard, and you will do well."

I think that that horse-race analogy must have been near and dear to John's heart. In the field of public speaking, John almost certainly started at the very back of the pack, as he had a very serious stutter. Although, I remember him stuttering when I was a medical student, I have not heard John stutter in more than 25 years, as he mastered the art of controlling it. It is truly amazing to me, that the young man who had a serious stutter went on to be an internationally acclaimed and highly sought after public speaker and lecturer, and perhaps the greatest lecturer the University of Toronto has ever seen. He was truly an inspiration. From his humble beginnings, he finished at the front of the pack. This no doubt sensitized and influenced him in the manner in which he approached all people and medical trainees in particular. Many interns and residents have worries and self doubts. Whatever the problem, John thought they should be able to overcome it. John made certain that he spotted and nurtured these people and that both he and they believed in their potential for success. If he could do it, they could do it. He encouraged them, and they ultimately succeeded.

Since his passing I have encountered many other individuals; doctors, nurses, secretaries, and patients who have stories that are similar to my own. John touched and changed their lives. and they and I wouldn' t be where we are today if it wasn't for him. The ripple effect of John's techniques, many good deeds and spheres of influence is vast and immeasurable.

The world is a far better place for having been graced with his presence. He will be sorely missed, yet his influence will live on. May his memory be a blessing.

\section{Warren Goldstein, MD}

Neurologist

Dr. John Gordon Edmeads was born in Toronto on April 15, 1936, and died there on November 16, 2006 of acute leukemia. He leaves his wife, Catherine Bergeron, a neuropathologist: his mother Beatrice, a son Christopher: brother Ralph and sister Marilyn Henry.

\section{Dr. John Edmeads 1936 - 2006}

Dr. John Gordon Edmeads of Toronto died on November 16, 2006 of leukemia at the age of 70. By any measure, he was a remarkable man, and made major contributions to the field of headache neurology both through his own work, and that of his students.

John Edmeads was best known to many of us who work in headache as a generous gracious man who had a silver tongue. No one could match his oratory, and a lecture by Dr. Edmeads was always well worth listening to, not only because the content was excellent, but also because the delivery was superb, and his wit always entertaining. He was simply a pleasure to listen to. For those of us who knew him less well, it was a shock to learn from an article published in the Globe and Mail after his death, that as a child and adolescent he had suffered from stuttering. Perhaps it is a good measure of the man that he so thoroughly overcame this disability.

John Edmeads started his headache career at a time when a focus on headache was perhaps even less popular in neurology than it is today. My first association with him was in 1972, when he was already an associate professor at the University of Toronto. At that time, among the physicians in the small northern Ontario community where I was a family physician, the word was that if you needed advice on a patient with a difficult headache problem, the patient was best referred for a consultation to Dr. Edmeads at Sunnybrook. Long before the triptans, he published his first article on headache, "Management of the acute attack of migraine" in $1973 .{ }^{1}$ It was however not the first of his 80 publications listed in Pub Med. That honor belongs to an article entitled "Diarrhea caused by pancreatic islet cell tumors" published in $1962 .^{2}$

Like the consultation letters he used to send me on my patients, publications by John Edmeads were always a good read. He had a clarity of style and a way with words that always kept the reader's attention. In 2002, while discussing the importance of making an accurate headache diagnosis, ${ }^{3}$ he commented on "...the usual impossibility of making a diagnosis of a headache by the now prevalent method of filling out imaging requests and laboratory requisitions, and the absolute need for history taking and physical examination skills and clinical judgment." A master communicator himself, he emphasized the importance of clear physician - patient communication in the same article by succinctly stating that, "Communicating the diagnosis is just as important as making it". 
John Edmeads made too many contributions and received too many honors over his long career to do them justice in a short article. He received the Hollington Award for Excellence in Undergraduate Teaching at the University of Toronto in 1988. He was made a lifetime honorary member of the Canadian Headache Society in 2000 . He was an outstanding ambassador for Canada in the field of headache, and was president of the American Association for the Study of Headache (now the American Headache Society) from 1980 to 1982. He received the John Graham award for international leadership in education and research in the field of headache from the same society in 1993. He served as Editor in Chief for the journal Headache from 1985 to 1991. He was head of Medicine and Physician in Chief at Sunnybrook Health Sciences Center, University of Toronto, from 1994 to 2001.

John Edmeads had an illustrious career, and was a role model for many young neurologists and other physicians. His modesty, humility, caring, and depth of knowledge had a profound influence on students and residents. The achievements of his students, in turn, were a great source of satisfaction for him. He was also very dedicated to patient care. Although well past the age where many retire, he continued to see patients with headache right up to the onset of his final illness.
Those of us who work in headache will remember him best for his personal charm, and the contributions he made in that field. Perhaps his career as a physician is best summed up by a quotation form Walter Alvarez, whom John Edmeads quoted in his paper "Communication Issues In Migraine Diagnosis"3 published in a supplement to the Canadian Journal of Neurological Sciences, "If I wanted to see what a consultant is made of, I'd refer him a patient with headache." John Edmeads was indeed a man up to this challenge, and his contributions will long be remembered, both by his colleagues, and perhaps more importantly, by his patients.

Werner J. Becker On behalf of the Canadian Headache Society

\section{REFERENCES}

1. Edmeads J. Management of the acute attack of migraine. Headache 1973; 13: 91-5.

2. Edmeads JG, Mathews RE, McPhedran NT, Ezrin C. Diarrhea caused by pancreatic islet cell tumours. Can Med Assoc J. 1962; 86: 847-51.

3. Edmeads J. Commnication issues in migraine diagnosis. Can $\mathbf{J}$ Neurol Sci. 2002; 29 Suppl.2: S8-10. 